\title{
Outcome-Based Education (OBE) Oriented Teaching Reform By Competitions
}

\author{
Hongtao Wang*, Xucheng Liu, Hui Huang \\ Faculty of Intelligent Manufacturing \\ Wuyi University \\ Jiangmen, China \\ nushongtaowang@qq.com
}

\author{
Dongyu Yang \\ The Fifth Research Institute of the Ministry of Industry and \\ Information Technology of China \\ Guangzhou, China
}

\begin{abstract}
In this paper, we got the benefits by using outcomebased education (OBE)-oriented teaching reform. The outcomebased education is an effective method to train students' abilities according to enterprises' demands, letting students adapt the work model from studying knowledge to the outcome. In this model, we can take the individual situation of students into account to design a suitable project. As an application of this method, the students from Wuyi University participate in teaching reforms in two approaches: one is competitions, and the other is college enterprise cooperation. Competitions will train the organization, communication and practice abilities of students, and being an internship in the enterprises will achieve the transform from students to qualified staff effectively. A survey of this program showing: the ninety-five percent of participators in the model of outcome-based education can get the desired occupation with a satisfying salary.
\end{abstract}

Keywords-Outcome-Based Education; Teaching Reform; Abilities; Desired Outcome

\section{INTRODUCTION}

With the rapid development of our country, the great demands of talents are becoming a common problem attracting the enterprises' and government's attention. However, at present, the traditional education method cannot cultivate perfect talents for society and enterprises with so many disadvantages [1]:

1) In terms of teaching arrangement, there are many problems in common courses, such as the large classes, fewer classes time, too many contents but outdated, etc.

2) There is a wide range of courses that cannot impart knowledge to students' interest.

3) Less opportunity to practice and communicate for students, thus they cannot improve their abilities in an actual environment.

4) Too simple indicator of performance appraisal.

Because of these questions mentioned, students are hardly interested in studying and improving their abilities under the heavy curriculum task. Thus, it is unavoidable to take teaching reforms to solve these issues.

Outcome-based Education (OBE) as an advanced

This study was supported by the Education Reform Project of Wuyl University No. 30727019 and No. JX201714, Undergraduate Teaching Quality and Teaching Reform Project in Wuyi University (JX2017001) Guangdong Undergraduate Teaching Quality and Teaching Reform Project (GDJX2017002) educational method, proposed by Spady in 1981, then get the recognition and attraction quickly, having become the main idea of American, England, Canadian, etc.[2] Since the American Engineering Certification Committee (ABET) has promulgated and implemented the EC2000 certification standards for learning and production, from the end of the twentieth century, the engineering education certification organizations in Europe and the United States have successively reformed the certification standards and taken the learning output as an important quality criterion[3]. Thus, based on the OBE higher objectives and professional training programs can be applied in teaching.

Outcoming Based Education' method is that the education goal of instructional design and teaching is to achieve the final learning outcoming through the education process. Its educational idea concentrates on the four essential problems, as follows:

1) What the result we want students to acquire?

2) Why we want students to acquire these achievements?

3) How to help students achieve these learning outcomes effectively?

4) How do we know that students have achieved these achievements?

To solve these problems, we design a detailed project for students of Wuyi University to improve the students' abilities. In the previous study, we applied CDIO method to achieve a good performance of participators in our previous teaching reform and obtained good results [4]. In the present teaching study, we take the OBE as the main evaluation index of education reform which provides an effective method to "students centered", and teaching students in accordance with their aptitude. The oriental object is to help students become the innovation learner who can learn the knowledge automatically, while the duty of the teacher is to become the instructor of students' learning, the provider of resources and organizer of the classroom activities. Teacher's responsibility is individualized guidance and answers questions [5]. Based on the OBE model, we can take the individual situation of students into account to design a suitable project. As an application of this method, the students from Wuyi University participate in teaching reforms in two approaches: one is competitions, and the other is college enterprise cooperation. Competitions will 
train the organization, communication and practice abilities of students, and being an internship in the enterprises will achieve the transform from students to qualified staff effectively.

\section{TEACHING OBJECTIVES}

As the idea of OBE, teaching objectives or learning achievements of courses are according to the graduation requirements of students. Determining the learning outcomes of the courses, we have to fully take the graduates' objectives into account. To solve the problems of teaching practice and cultivate qualified graduates for enterprises and society, Wuyi University investigated the requirement of students, concluding the teaching objectives as the following section.

\section{A. Establishing a Multi-Level Practice Teaching System}

In view of traditional education, it focuses on syllabi, teaching and examination, but there is a lacking of emphasis on skills needed in work, e.g. communication skills, office skills and human relationships skills [6]. The teaching structure is too simple to cultivate the qualified talents who can master scientific experimental method and basic practical skills and rich professional knowledge. The multi-level practice teaching system should contain three-level programs in response to the demands of practice, including: basic type, comprehensive design type and academic type. Focusing on the curriculum experiment and curriculum design, basic type mainly examines students' understanding of the knowledge they have learned, and it plays an important role in cultivating the abilities of innovation and practice. The comprehensive design type is based on professional practice, comprehensive experiment and graduation design to improve the comprehensive design ability of students to solve practical problems with their knowledge. The academic type is mainly based on the college enterprise cooperation and the science and technology competition project, train the students to use the knowledge and skills they have learned to strengthen their practical abilities.

\section{B. Establishing a Comprehensive Practice Base to Combining Production, Learning and Research}

Teaching should never be limited in the class; we should know the demands of the enterprise. Establishing a comprehensive practice base is a good approach to combine the college with enterprise, making students adapt the identity transform from students to qualified staff, improving the basic production skills, enhancing the engineering consciousness.
Students can choose their interesting project to take long-term practice in the enterprise.

\section{Strengthening the Construction of Double Teachers' team}

College should invite the experts from related enterprise to occupy the part-time teacher guiding students to carry out practical teaching. On the other hand, providing an opportunity for teachers, especially young teachers, communicate with experts to improve their teaching ability. Moreover, advocating double tutorial system, that is tutors in the college and enterprise together to guide students to complete practical activities.

\section{Establishing a Multidimensional Evaluation Method}

Establishing an evaluation method which is the kernel of study outcoming, setting the suitable weight of evaluation, introducing the other evaluation subjects except for teachers, can evaluate students with a more scientific and comprehensive way. Introducing self-evaluation to students, let students score their abilities, furthermore, introducing mutual evaluation between students, that make students recognize their abilities and improve their abilities.

\section{The TEACHING REFORM OF WUYI UNIVERSITY}

The great demands of innovation and practical talents are the impetus of reform. Enterprises and society urgently need students with professional skills [7]. Outcoming based education can meet the demand of these, and taking the demands as the goal, saving them time and cost of the enterprise to train students, keeping a rapid development of enterprise.

\section{A. Participating Various Competitions}

Aiming at improving abilities of students, Wuyi University organized students to participate in provincial level and national level competitions, such as Holtek cup SCM application design contest, Freescale Cup national college students' intelligent car competition, national undergraduate electronics design contest and many competitions held by the college. These competitions require students to have the full skills of organization, communication, and practice, every one of the team has their own responsibility, some organize the meeting, some search papers and some make productions. The achievements of recent years (2014-2019) by outcome-based education are summarized in TABLE I:

TABLE I. THE ACHIEVEMENTS OF THE OUTCOME-BASED EDUCATION-ORIENTED TEACHING REFORMS BY COMPETITIONS

\begin{tabular}{|c|l|l|}
\hline $\mathbf{N o}$ & \multicolumn{1}{|c|}{ Project Name } & \multicolumn{1}{|c|}{ Award } \\
\hline $\mathbf{1}$ & Intelligent Warehouse Car & $\begin{array}{l}\text { The first prize of the fifth Guangdong "Holtek Cup" single chip competition in } \\
2014\end{array}$ \\
\hline $\mathbf{2}$ & Cloud Computing Intelligent Garbage Collection System & $\begin{array}{l}\text { The second prize of the fifth Guangdong "Holtek Cup" single chip competition } \\
\text { in } 2014\end{array}$ \\
\hline $\mathbf{3}$ & Outdoor Adventure Smart Flashlight & $\begin{array}{l}\text { The second prize of the fifth Guangdong "Holtek Cup" single chip competition } \\
\text { in } 2015\end{array}$ \\
\hline $\mathbf{4}$ & Quadruped Crawler Robot & $\begin{array}{l}\text { The third prize of the fifth Guangdong "Holtek Cup" single chip competition in } \\
2015\end{array}$ \\
\hline $\mathbf{5}$ & Order Portable Table Automatic Table System & $\begin{array}{l}\text { The third prize of the fifth Guangdong "Holtek Cup" single chip competition in } \\
2015\end{array}$ \\
\hline
\end{tabular}


Cont. to TABLE I.

\section{$6 \quad$ Arm Trolley}

7 Healthy Growth of Young People

8 Freshwater Aquaculture System Based on the Technology of Internet of Things

9 Transmission of Android Smart Baby Bed Based on WIFI

10 Multi Sensor Intelligent Window Remote Monitoring System Based on Internet of Things

1 Design of Two Wheeled Self -Balancing Vehicle Based on MultiMode Cooperative Control

12 Based on NRF and GSM Remote Alarm System Design of Family Security System

13 Cloud Computing Based Multi Sensor Intelligent Window Remote Monitoring System

14 ARM9 Based Smart Home System

15 Monitoring and Early Warning Mechanism of Human Physiological Information Based on Large Data

16

Full-automatic aquaculture system based on intelligent cruise robot

17 Bionic Hands in Demonstration Teaching Based on HT32F52352

18 Smart Shoe Cabinet

19

Access Control System for Finger Vein Recognition Based on Hetai MCU

EEG Driving Fatigue Detection System Based on Wireless Dry Electrode

21 Driving Fatigue Detection System Based on brain functional 21 Connectivity

22 Automatic Navigation AGV Car

23 Metal Surface Monitoring System Based on Machine Vision

24 Bionic teaching manipulator

25 Stereo Vision System

26 Face Recognition Access Control System

\section{B. College-Enterprise cooperation}

Wuyi University has built a college enterprise cooperation with The Fifth Research Institute of The Ministry of Industry and Information Technology of China, which is established in 1955, is the earliest authoritative institute working about reliability research. Students can participate in this program to improve their abilities oriented towards the specific demands of the enterprise. Thus, students can achieve the transform from students to qualified staff. The outcome of the Fifth Electronic Institute requires students to complete the task of software design or hardware design, so we divided students into 2 teams refer to the interest of everyone.

\section{The Result And Future DeVelopment TREnd}

Through the policy based on OBE, we achieve the teaching reform to cultivate the talents with more innovation and practical abilities. According to the result-oriented training mode, we invite enterprises to take part in the teaching, so that
The first prize of the fifth Guangdong "Holtek Cup" single chip competition in 2015

The second prize of the fifth Guangdong "Holtek Cup" single chip competition in 2016

The second prize of the fifth Guangdong "Holtek Cup" single chip competition in 2016

The third prize of the fifth Guangdong "Holtek Cup" single chip competition in 2016

The first prize of the fifth Guangdong "Holtek Cup" single chip competition in in 2017

The third prize of the fifth Guangdong "Holtek Cup" single chip competition in 2017

The third prize of the fifth Guangdong "Holtek Cup" single chip competition in 2018

The second prize of national information technology application in 2018

The second prize of the first National University IOT innovation competition of Southern China District in 2018

The second prize of the first National University IOT innovation competition of Southern China District in 2018

The first prize of the fifth Guangdong "Holtek Cup" single chip competition in 2019

The second prize of the fifth Guangdong "Holtek Cup" single chip competition in 2019

The third prize of the fifth Guangdong "Holtek Cup" single chip competition in 2019

The third prize of the fifth Guangdong "Holtek Cup" single chip competition in 2019

The third prize in the National University Competition on Innovative Application of Human Brain Computing in 2017

The 13th Postgraduate Electronic Design Competition in 2018

The 13th Postgraduate Electronic Design Competition in 2018

The 13th Postgraduate Electronic Design Competition in 2018

The 14th Postgraduate Electronic Design Competition in 2019

The 14th Postgraduate Electronic Design Competition in 2019

The 14th Postgraduate Electronic Design Competition in 2019

the training of students will be carried out under the conditions of market demands, avoiding the disjunction of talent training and market demands, which lays a perfect foundation for students' employment after graduates. The internship can make students enter the state of enterprise work ahead of time, greatly improve students' engineering practice ability [8-10]. Through the above methods, establishing the outside college practical base can achieve the win-win situation of college and enterprise.

Outcome-based education has become a significant method of college education, it can meet the demands of enterprise and society, implementing the multiple teaching methods according to expect the outcome of students [11-13]. In our teaching reform, nighty percent of participators got the rewards from competitions, compared with students who did not participate in. The participators obtain better abilities in many aspects: research, organization, communication, practice, etc. This also proves that the outcome-based education-oriented teaching 
reforms by competitions is an effective way to promote the quality of teaching.

\section{CONCLUSION}

Outcome-based education cultivates the talents according to the demands of enterprise and society, avoiding students cannot adapt to the market[14-16]. Based on the OBE model, we can take the individual situation of students into account to design a suitable project. As an application of this method, the students from Wuyi University participate in teaching reforms in two approaches: one is competitions, and the other is college enterprise cooperation. During the application of the proposed teaching reform. From the year 2014 to 2019, there are twentysix competitions which students participated in. The results demonstrate that competition could really help to train the organization, communication and practice abilities of students, and being an internship in the enterprises will achieve the transform from students to qualified staff effectively. Furthermore, by participating in various competitions training students' organization, communication and practice abilities or being an internship in the enterprise, students get the perfect result from the engineering training. In a survey of students who participate in the method of outcoming-based education, ninety-five percent of students get the occupation with a satisfying salary.

\section{REFERENCES}

[1] Saroj Jain. Outcomes-Based Education: Need of Present Scenario[J]. Journal of Innovative Research and Development, 2016: 18-22

[2] Xuan Lingyan, Shen Yanli, Li Jun. Teaching Reform Practice of Civil Engineering English Based on OBE Education Concept[J]. Journal of Hebei University of Engineering (Social Science), 2018, 35(02): $127-$ 129 (In Chinese)

[3] Peng Duan, Jiang Lili, Chen An, Du Yushang, Chen Lingmin. Exploration of Modern Digital Electronic Technology Experiment Based on OBE Mode[J]. Chinese Modern Educational Equipment, 2017(13):25-27 (In Chinese)

[4] Wang Hongtao, Dong Chaojun, Huang Hui. Application Research of CDIO in Single Chip Microprocessor-Based Graduation Design[A] 11th International Conference on Innovation and Management (ICIM 2014) [C]. Univ Vaasa, Vaasa, Han University of Technology, 2014.4: $1287-1290$

[5] Tu Xiaoyun. Application of Educational Philosophy Based on OBE in Teaching Reform of Java Web Foundation[J]. Fujian Computer, 2018(06):157-158 (In Chinese)

[6] Xiao Zhitao, Wu Jun, Geng Lei, etc. Practice Teaching Reform of Electronic Information Class Undergraduate Programs Based on OBE Idea[J]. Education Teaching Forum, 2018(26):117-118.(In Chinese)

[7] Wang Shanshan, Meng Xiangxin. Discussion on The Way to Cultivate Students' Innovative and Entrepreneurial Ability Based on OBE Concept[J]. Higher Academic Journals, 2018(12):38-40(In Chinese)

[8] Liu Yancong, Li Jun. Design of Training Program for Applied Technology Talents Based on OBE Concept[J]. Vocational and Technical Education in China, 2018(14):72-76+96(In Chinese)

[9] Halbleib M L, Jepson P C. Adapting an Outcome-Based Education Development Process to Meet Near Real-Time Challenges to Sustainable Agricultural Production[J]. Journal of Agricultural Education \& Extension, 2015, 21(2):109-126.

[10] Telsang M T. Outcome Based Education - Design Delivery and Assessment of Product Design and Development Course at Undergraduate Engineering Program[J]. Urology, 2015, 50(5):145.

[11] Herbert Bheki Khuzwayo, Dumsani Wilfred Mncube. Progressive mathematics teaching in South Africa: a focus on curriculum reform from Outcomes-Based Education (OBE) to the Curriculum and Assessment Policy Statement (CAPS). 2017.1123-1127

[12] Ying-Han C, Guang-Ling Z, Hong-Yong Y, et al. Practical Teaching Reform based on OBE Educational Idea[J]. Jiangxi Chemical Industry, 2018

[13] Liping H, Wang X, Wang Z, et al. Teaching Reform and Exploration of Biomimetic Materials Chemistry[J]. University Chemistry, 2018 33(4).345-351

[14] Xie R, Fulan Y E. Research on the Practical Teaching Reform of Information Management and Information System[J]. Journal of Beijing City University, 2018.456-462

[15] Gleeson J, Sugrue C, O'Flaherty J. Research capacity and initial teacher education reform: Irish experiences, international perspectives[J]. Teaching \& Teacher Education, 2017, 62(Complete):19-29.

[16] Yuan G, Bing $\mathrm{K}$, Ding $\mathrm{H}$, et al. Teaching Reform and Exploration on Object-Oriented Programming[C]// International Conference on Computational Science \& Computational Intelligence. 2016 